\title{
Exosurf Rescue Surfactant Improves High Ventilation-Perfusion Mismatch in Respiratory Distress Syndrome
}

\author{
Daniel Billman, $\mathrm{MD}^{1}{ }^{1}$ Joanne Nicks, $\mathrm{RRT}^{2}$ and Robert Schumacher, $\mathrm{MD}^{3}$
}

\begin{abstract}
Summary. Objective: To assess ventilation/perfusion $\left(\dot{V}_{A} / \dot{Q}\right)$ mismatch of the high type, following rescue surfactant therapy for respiratory distress syndrome. Hypothesis: Surfactant therapy reduces such mismatch. Design: Randomized, double-blind, placebo-controlled study, assessing $\mathrm{V}_{\mathrm{A}} / \mathrm{Q}$ with the arterial-alveolar difference of $\mathrm{CO}_{2}$ tension $\left(\mathrm{P}_{(\mathrm{a}-\mathrm{A}) \mathrm{CO}_{2}}\right)$. This difference was determined with capnometry and arterial blood gases, using the equation: $P_{(\mathrm{a}-\mathrm{A}) \mathrm{CO}_{2}}$ equals arterial $\mathrm{CO}_{2}$ minus alveolar $\mathrm{CO}_{2}$ partial pressure. Setting: A level III nursery. Patients: Ten intubated infants with respiratory distress syndrome. Intervention: Infants were randomized to each receive two doses of surfactant or two doses of air placebo. Results: $\mathrm{P}_{(\mathrm{a}-\mathrm{A}) \mathrm{CO}_{2}}$ improved after surfactant and worsened after placebo $(P=0.0021)$, comparing slopes of 12 -hr regression lines. A similar pattern occurred with oxygenation. These changes in $\mathrm{P}_{(\mathrm{a}-\mathrm{A}) \mathrm{CO}_{2}}$ and in oxygenation were minimally correlated within the surfactant group. Conclusion: Exosurf rescue surfactant reduced $\dot{V}_{A} / \dot{Q}$ mismatch of the high type, over several hours. Pediatr Pulmonol. 1994; 18:279 283. (c) 1994 Wiley-Liss, inc.
\end{abstract}

Key words: Arterial-alveolar $\mathrm{CO}_{2}$ tension, alveolar-arterial $\mathrm{O}_{2}$ tension, alveolar/arterial $\mathrm{O}_{2}$ tension, oxygenation index, mean airway pressure.

\section{INTRODUCTION}

Surfactant therapy has reduced mortality in premature infants by treating or preventing respiratory distress syndrome (RDS). ${ }^{1}$ Surfactant treatment commonly improves oxygenation within $0-2 \mathrm{hr}^{1-5}$ and improves lung compliance later. ${ }^{5-7}$ Little has been published about how surfactant therapy affects alveolar ventilation-perfusion ratios $\left(\dot{\mathrm{V}}_{\mathrm{A}} / \dot{\mathrm{Q}}\right)$. We hypothesized that rescue surfactant therapy would improve $\dot{V}_{\mathrm{A}} / \mathrm{Q}$ mismatch of the high type.

The lung model assessed by this study involves high $\dot{\mathrm{V}}_{\mathrm{A}} / \dot{\mathrm{Q}}$ regions of the lung. ${ }^{8-11}$ Ideally $\dot{\mathrm{V}}_{\mathrm{A}} / \mathrm{Q}$ is close to 1.0 in most lung regions. In diseased lungs there can be mismatches involving high $\dot{\mathrm{V}}_{\mathrm{A}} / \dot{\mathrm{Q}}$ regions, low $\dot{\mathrm{V}}_{\mathrm{A}} / \dot{\mathrm{Q}}$ regions, or both. Both types of mismatch can occur simultaneously in RDS. ${ }^{12}$ Regions of high $\dot{\mathrm{V}}_{\mathrm{A}} / \dot{\mathrm{Q}}$ contribute to increased dead space. If dead space becomes excessive, $\mathrm{CO}_{2}$ retention results. Regions of low $\dot{\mathrm{V}}_{\mathrm{A}} / \dot{\mathrm{Q}}$ can act as small venoarterial shunts. Blood perfusing such regions can be incompletely oxygenated with decreased $\mathrm{CO}_{2}$ removal.

This study monitored the arterial-alveolar difference of $\mathrm{CO}_{2}$ tension $\left(\mathrm{P}_{(\mathrm{a}-\mathrm{A}) \mathrm{CO}_{2}}\right)$. This is defined as $\mathrm{P}_{(\mathrm{a}-\mathrm{A}) \mathrm{CO}_{2}}=$ $\mathrm{P}_{\mathrm{aCO}}-\mathrm{P}_{\mathrm{ACO}_{2}}$, which relates the partial pressure of arterial $\mathrm{CO}_{2}\left(\mathrm{P}_{\mathrm{aCO}}\right)$ and the partial pressure of alveolar $\mathrm{CO}_{2}$ $\left(\mathrm{P}_{\mathrm{ACO}_{2}}\right){ }^{8-11}$ The $\mathrm{P}_{\mathrm{aCO}}$ was measured with arterial blood gases, and $\mathrm{P}_{\mathrm{ACO}_{2}}$ was assessed with capnometry. The $\mathrm{P}_{(\mathrm{a}-\mathrm{A}) \mathrm{CO}_{2}}$ value is a widely accepted gauge of high $\dot{\mathrm{V}}_{\mathrm{A}} / \dot{\mathrm{Q}}$ (C) 1994 Wiley-Liss, Inc. lung regions ${ }^{8-11}$ and is minimally influenced by low $\dot{\mathrm{V}}_{\mathrm{A}} / \dot{\mathrm{Q}}$ regions. ${ }^{12}$ For assessing high $\dot{\mathrm{V}}_{\mathrm{A}} / \dot{\mathrm{Q}}$ mismatch, $\mathrm{P}_{(\mathrm{a}-\mathrm{A}) \mathrm{CO}_{2}}$ is much more reliable than $\mathrm{P}_{\mathrm{aCO}}$ because the latter is influenced by right-to-left shunting and other factors. The normal range for $\mathrm{P}_{(\mathrm{a}-\mathrm{A}) \mathrm{CO}_{2}}$ may be as narrow as $0-2 \mathrm{~mm} \mathrm{Hg}$ in healthy adults, ${ }^{\circ}$ but may be as wide as $0-12 \mathrm{~mm} \mathrm{Hg}$ in healthy premature infants. ${ }^{13}$ In this study, analysis focused on $\mathrm{P}_{(\mathrm{a}-\mathrm{A}) \mathrm{CO}_{2}}$ changes over time rather than absolute levels.

From the Department of Pediatrics, Neonatal Section, Medical College of Wisconsin, Milwaukee, Wisconsin, ${ }^{1}$ and the Departments of Pediatric Respiratory Therapy ${ }^{2}$ and Pediatrics, Section of Newborn Services, ${ }^{3}$ University of Michigan Medical Center, Ann Arbor, Michigan.

Received March 9, 1994; (revision) accepted for publication June 28, 1994.

This research exclusively involved patients at the University of Michigan Medical Center; it had no support from a manufacturer or a grant.

Presented as a poster at the Midwest Society for Pediatric Research in Chicago, Illinois, November 3, 1993.

Address correspondence and reprint requests to Dr. D. Billman, MCMC, Box 174, 8700 W. Wisconsin Ave., Milwaukee, WI 53226. 


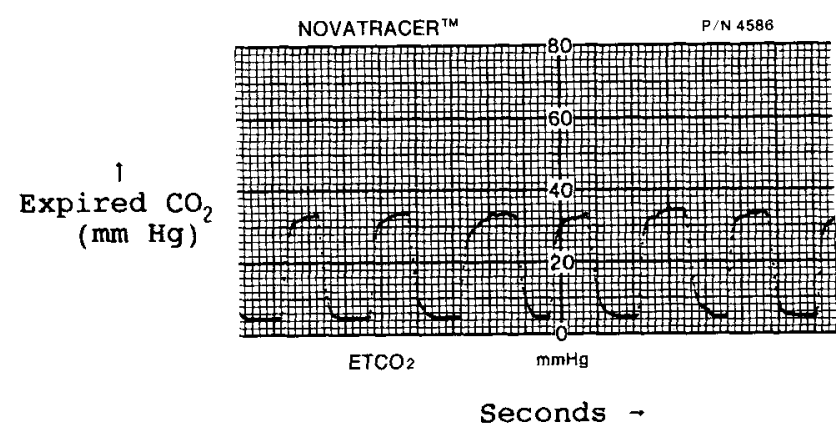

Fig. 1. A capnometric tracing of partial pressure of $\mathrm{CO}_{2}$ during tidal breathing (plateaus at end-expiration approximate alveolar $\mathbf{P}_{\mathrm{CO}_{2}}$ ).

\section{MATERIALS AND METHODS}

Ten premature infants with RDS were monitored for respiratory parameters, to compare the response to surfactant with the natural course of RDS between 2 to $48 \mathrm{hr}$ of age. All 10 patients were born in 1989 and cared for at the University of Michigan Medical Center. They were a subset of the 1656 infants in two randomized doubleblind multicenter trials conducted by the manufacturer of Exosurf (Colfosceril Palmitate, Cetyl Alcohol, Tyloxapol: made by Burroughs-Wellcome Co., Research Triangle Park, North Carolina). ${ }^{2,3}$

These 10 infants were selected from a consecutive series of infants admitted to the hospital. The selection was solely based on meeting two criteria: (1) enrollment in one of these Exosurf trials, ${ }^{2,3}$ and (2) having continuous monitoring of the partial pressure of end-tidal $\mathrm{CO}_{2}$ $\left(\mathrm{P}_{\mathrm{etCO}}\right)$. Exosurf was dosed endotracheally in a dose of 5 $\mathrm{mL} / \mathrm{kg}$ (67.5 mg phospholipid $/ \mathrm{kg}$ ). Control infants received a doses of $5 \mathrm{~mL} / \mathrm{kg}$ sham air. The first treatment dose was given to enrolled infants with significant RDS, who met certain requirements, ${ }^{2,3}$ including age $\leqslant 24 \mathrm{hr}$, the need for mechanical ventilation, and a ratio of $<0.22$ between the partial pressure of arterial oxygen $\left(\mathrm{P}_{\mathrm{aO}_{2}}\right)$ and the partial pressure of alveolar oxygen $\left(\mathrm{P}_{\mathrm{AO}_{2}}\right)$. One repeat dose of Exosurf or air was given to all 10 patients $\geqslant 12 \mathrm{hr}$ after the first dose. The ventilation techniques usually maintained a $\mathbf{P}_{\mathrm{aCO}}$ of $35-50 \mathrm{~mm} \mathrm{Hg}$ during this study's evaluation periods.

The following were concurrently measured with capnometry and other methods: $\mathrm{P}_{\mathrm{etCO}},{ }^{14}$ fraction of inspired oxygen $\left(\mathrm{F}_{\mathrm{iO}_{2}}\right)$, mean airway pressure (MAP), $\mathrm{P}_{\mathrm{aO}}$, and $\mathrm{P}_{\mathrm{aCO}}$. Data sets of these 5 measurements were obtained when clinicians ordered arterial blood gases. The blood samples were obtained from indwelling arterial catheters, usually umbilical catheters at 8-10 level thoracic vertebrae. Capnometry measured partial pressure of expired $\mathrm{CO}_{2}$. Pressure of expired $\mathrm{CO}_{2}$ at end-expiration (Fig. 1) approximates $\mathrm{P}_{\mathrm{ACO}_{2}}$ if adequate gas mixing has occurred. The readings of $\mathrm{P}_{\mathrm{etCO}}$ were made on the Novametrix

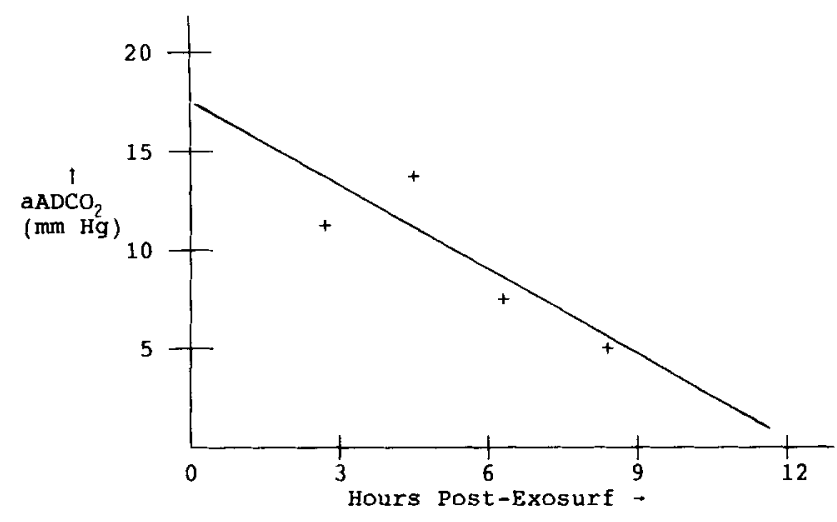

Fig. 2. Regression line of $\mathbf{P}_{(\mathrm{a}-\mathrm{A}) \mathrm{CO}_{2}}$ arterial-alveolar $\mathrm{CO}_{2}$ pressure $\left[\mathrm{aADCO} \mathrm{O}_{2}\left(\mathrm{P}_{(\mathrm{a}-\mathrm{A}) \mathrm{CO}_{2}}\right.\right.$ in the text)] on time after treatment dose in one patient.

1260 capnometer with a mainstream infrared design (Wallingford, Connecticut). ${ }^{15}$ These measurements are noninvasive and the instruments provide graphic printouts. Printouts were obtained for almost all of the data sets, which demonstrated good plateaus of $\mathrm{P}_{\mathrm{etCO}}$ (Fig. 1). The plateau occurs after the mixing of expired gases when $\mathrm{P}_{\text {erCO }} \cong \mathrm{P}_{\mathrm{ACO}_{2}}$. The capnometer was calibrated daily using its internal system, using one gas with zero $\mathrm{CO}_{2}$ and another with a known $\mathrm{CO}_{2}$ concentration.

Values for $\mathrm{P}_{(\mathrm{a}-\mathrm{A}) \mathrm{CO}_{2}}$ and for three parameters of oxygenation $\left[\mathrm{P}_{(\mathrm{A}-\mathrm{a}) \mathrm{O}_{2}}, \mathrm{P}_{\mathrm{AO}_{2}} / \mathrm{P}_{\mathrm{aO}_{2}}\right.$, and oxygenation index (OI)] were calculated for each data set. The OI is defined as (fraction of inspired oxygen) $\times(100 \times \mathrm{MAP}) / \mathrm{P}_{\mathrm{aO}_{2}}{ }^{16}$ The ratio $\mathrm{P}_{\mathrm{AO}_{2}} / \mathrm{P}_{\mathrm{aO}_{2}}$ rather than $\mathrm{P}_{\mathrm{aO}_{2}} / \mathrm{P}_{\mathrm{AO}_{2}}$ was used so that changes in the three oxygenation parameters would match in direction. Standard equations were used including the alveolar air equation for determining $\mathrm{P}_{\mathrm{AO}_{2}}$ and $\mathrm{P}_{(\mathrm{A}-\mathrm{a}) \mathrm{O}_{2}} \cdot{ }^{10} \mathrm{~A}$ respiratory exchange ratio of 0.8 was used, since the patients were not yet receiving intravenous lipids. ${ }^{10}$

The timed data sets were statistically analyzed if they met all of the following criteria: (1) data obtained 0-12 hours following a dose of surfactant or air, (2) existence of $\geqslant 3$ sets during the $12 \mathrm{hr}$ interval, and (3) data appearing reliable by visual assessment, to exclude sets with an outlier $\mathrm{P}_{(\mathrm{a}-\mathrm{A}) \mathrm{CO}_{2}}$ ( 3 sets of 67 were thus excluded). Since individual doses were separated by $\geqslant 12 \mathrm{hr}$ (Exosurf protocol ${ }^{2,3}$ ), none of these $12 \mathrm{hr}$ postdose intervals had overlapping data sets. Therefore, each data set within one such interval was statistically analyzed for only that interval's dose (Fig. 2). Negative $\mathrm{P}_{(\mathrm{a}-\mathrm{A}) \mathrm{CO}_{2}}$ was not an exclusion criterion. Five of the final 64 data sets had such values, ranging from -1 to $-3 \mathrm{~mm} \mathrm{Hg}$. This phenomenon may have indicated calibration error or lack of a steady state within the lungs. A negative $\mathrm{P}_{(\mathrm{a}-\mathrm{A}) \mathrm{CO}_{2}}$ can occur during exercise. ${ }^{17}$

Regression lines for $\mathrm{P}_{(\mathrm{a}-\mathrm{A}) \mathrm{CO}_{2}}$ were plotted against time over the $12 \mathrm{hr}$ postdose intervals (Fig. 2). The $X$-axis was 
TABLE 1-Population Characteristics

\begin{tabular}{lccc}
\hline & Exosurf & Control & $P$ \\
\hline$n$ (male, female) & $5(4,1)$ & $5(4,1)$ & \\
Inborn:outborn & $3: 2$ & $4: 1$ & \\
Gestational age $^{1}$ (weeks) & $31.1 \pm 2.7$ & $29.8 \pm 1.9$ & 0.41 \\
& $(26.5-33.0)$ & $(28.0-33.0)$ & \\
Birth weight $^{1}(\mathrm{~g})$ & $1614 \pm 523$ & $1516 \pm 428$ & 0.75 \\
& $(850-2120)$ & $(1160-2108)$ & \\
High frequency jet ventilation $^{2}$ & $20 \%$ & $40 \%$ & $20 \%$ \\
Mortality $^{2,3}$ & $20 \%$ &
\end{tabular}

${ }^{1}$ Continuous data given as mean $\pm \mathrm{SD}$ (range).

${ }^{2}$ Occurred after this study's evaluation.

${ }^{3}$ Each from respiratory causes.

TABLE 2-Timing and Conditions for Evaluated Doses

\begin{tabular}{lcc}
\hline & Exosurf & Control \\
\hline$n$ (dose 1,dose 2) & $8(3,5)$ & $7(2,5)$ \\
Hours, postnatal age & & \\
At dose 1 & 10.3 & 5.5 \\
At dose 2 & $(4.6-14.1)$ & $(3.7-7.2)$ \\
& 25.8 & 17.4 \\
Respiratory parameters ${ }^{1}$ & $(14.1-36.4)$ & $(14.5-20.3)$ \\
$\quad \mathrm{P}_{(\mathrm{a}-\mathrm{A}) \mathrm{CO}_{2}}$ & 6.5 & 8.9 \\
$\quad(\mathrm{~mm} \mathrm{Hg})$ & & \\
$\mathrm{P}_{(\mathrm{A}-\mathrm{a}) \mathrm{O}_{2}}$ & 251 & 357 \\
$(\mathrm{~mm} \mathrm{Hg})$ & & \\
$\mathrm{P}_{\mathrm{AO}} / \mathrm{P}_{\mathrm{aO}}$ & 3.4 & 5.6 \\
$\mathrm{OI}^{2}$ & 5.3 & 8.1 \\
\hline
\end{tabular}

${ }^{1}$ Mean (range).

${ }^{2}$ Means of line intercepts at dosing time (Fig. 2); OI,oxygenation index.

calibrated to the nearest minute, and the $Y$-axis to the nearest $\mathrm{mm} \mathrm{Hg}$ or to $\geqslant 2$ decimal places. Although linear representation might oversimplify the changes in $\mathrm{P}_{(\mathrm{a}-\mathrm{A}) \mathrm{CO}_{2}}$ and in oxygenation, it makes it possible to assess mutual correlations between these changes. ${ }^{18} \mathrm{We}$ used the Pearson r-coefficient to quantitate these correlations. ${ }^{18}$ All $P$-values were two-tailed.

For each patient in this study, parents gave written informed consent for treatment with either Exosurf or placebo, and for data collection and analysis.

\section{RESULTS}

The 10 infants in this study were randomized to receive or to not receive Exosurf. The two resulting groups were fairly similar by the data in Table 1; they had a combined gestational age of $30.5 \pm 2.3$ weeks and birth weight of $1565 \pm 478 \mathrm{~g}$ (mean $\pm \mathrm{SD}$ ). Table 2 gives estimates for $\mathrm{P}_{(\mathrm{a}-\mathrm{A}) \mathrm{CO}_{2}}$ and for oxygenation parameters at the times of dosing. Instead of a potential of 20 doses 15 were evaluated to meet the requirement of $\geqslant 3$ data sets per dose. Table 2 also shows the mean postnatal ages at each of the 15 doses assessed in this study. Exosurf doses were given
TABLE 3-Hourly Changes in Respiratory Parameters ${ }^{1}$

\begin{tabular}{lccc}
\hline & Exosurf & Control & $P$ \\
\hline $\mathrm{P}_{(\mathrm{a}-\mathrm{A}) \mathrm{CO}} / \mathrm{hr}$ & -0.63 & +0.39 & 0.0021 \\
$(\mathrm{~mm} \mathrm{Hg} / \mathrm{hr})$ & & & \\
$\mathrm{P}_{(\mathrm{A}-\mathrm{a}) \mathrm{O}_{2}} / \mathrm{hr}$ & -9.3 & +3.7 & 0.011 \\
$(\mathrm{~mm} \mathrm{Hg} / \mathrm{hr})$ & & & \\
$\mathrm{P}_{\mathrm{AO}} / \mathrm{P}_{\mathrm{aO}_{2}} / \mathrm{hr}$ & -0.08 & +0.15 & 0.095 \\
$\mathrm{OI} / \mathrm{hr}$ & -0.17 & +0.33 & 0.052 \\
\hline
\end{tabular}

'Means of slopes of regression; for abbreviations see text.

TABLE 4-Correlations Between Changes of $P_{(a-A) C O}$ and Other Respiratory Parameters ${ }^{1}$

\begin{tabular}{lccccc}
\hline & \multicolumn{2}{c}{ Exosurf } & & \multicolumn{2}{c}{ Control } \\
\cline { 2 - 3 } \cline { 5 - 6 } Parameters & $r$ & $P$ & & $r$ & $P$ \\
\hline $\mathrm{P}_{(\mathrm{A}-\mathrm{a}) \mathrm{O}_{2}}$ & -0.22 & 0.60 & +0.47 & 0.29 \\
$\mathrm{P}_{\mathrm{AO}_{2}} / \mathrm{P}_{\mathrm{aO}_{2}}$ & -0.21 & 0.62 & & +0.83 & 0.02 \\
$\mathrm{OI}$ & -0.12 & 0.78 & & +0.71 & 0.07 \\
\hline
\end{tabular}

${ }^{1}$ For abbreviations see text.

at an average of about $7 \mathrm{hr}$ later than placebo doses. This difference was likely a chance variation, but does not invalidate the outcome data.

Table 2 does not provide preintervention "baseline" comparisons. Many of the evaluated doses were second doses, thus the differences in the respiratory parameters reflect whether or not surfactant had previously been given. The groups were too small for reliable comparisons for only the first dose. The disparities in Table 2 regarding postnatal ages and respiratory parameters do not invalidate the outcome data presented in Tables 3 and 4. The outcome comparisons involve the changes during $12 \mathrm{hr}$ postdose intervals, rather than absolute values. All of these intervals were within the first 2 days of life, presumably the early worsening phase of RDS.

During the $12 \mathrm{hr}$ posttreatment intervals, $\mathrm{P}_{(\mathrm{a}-\mathrm{A}) \mathrm{CO}_{2}}$ usually decreased after surfactant doses and usually increased after air doses. Regression lines for $\mathrm{P}_{(\mathrm{a}-\mathrm{A}) \mathrm{CO}_{2}}$ on time demonstrated such patterns following 7 of the 8 surfactant doses evaluated and following 6 of the 7 air 
doses evaluated $(P<0.05$ by chi square). A total of 64 data sets were analyzed, i.e., a mean of 4.3 sets per dose (range, 3 to 8). Data spanned over 5 to $10 \mathrm{hr}$ per dose, for determining regression lines. These lines showed changes in $\mathrm{P}_{(\mathrm{a}-\mathrm{A}) \mathrm{CO}_{2}}$ : The slopes of the lines for $\mathrm{P}_{(\mathrm{a}-\mathrm{A}) \mathrm{CO}_{2}}$ averaged $-0.63 \mathrm{~mm} \mathrm{Hg} / \mathrm{hr}$ following surfactant and $+0.39 \mathrm{~mm} \mathrm{Hg} / \mathrm{hr}$ after air $(P=0.0021$; Table 3$)$. These data support that Exosurf reduced high $\dot{\mathrm{V}}_{\mathrm{A}} / \dot{\mathrm{Q}}$ lung regions for several hours.

Trends for oxygenation $\left(\mathrm{P}_{(\mathrm{a}-\mathrm{A}) \mathrm{CO}_{2}}, \mathrm{P}_{\mathrm{AO}_{2}} / \mathrm{P}_{\mathrm{aO}}, \mathrm{OI}\right)$ were similar to the trends for $\mathrm{P}_{(\mathrm{A}-\mathrm{a}) \mathrm{O}_{2}}$ (Table 3). Oxygenation improved following surfactant and worsened following air; with the respective slopes of regression lines being significantly different by $P$-values of 0.01 to 0.1 . Even though these overall trends were similar, patients receiving surfactant lacked strong correlations between the slopes of regression lines for $\mathrm{P}_{(\mathrm{a}-\mathrm{A}) \mathrm{CO}_{2}}$ and for oxygenation changes $(r \cong-0.1$ to -0.2 , Table 4$)$. In patients receiving air, correlations between these two items were moderately positive ( $r \cong+0.5$ to +0.8 ; Table 4$)$.

During this study, the main clinical problem of each patient was RDS (specifically, the early worsening phase of RDS). Up to $12 \mathrm{hr}$ after the second dose, no infant had a pneumothorax and no infant was started on high frequency jet ventilation. The $\mathrm{P}_{\mathrm{et}_{\mathrm{CO}}}$ can change dramatically with an acute event such as a pneumothorax, ${ }^{14,16}$ however, clinically all 10 infants appeared to have RDS without such events throughout the study intervals.

\section{DISCUSSION}

Our main finding was that rescue Exosurf lowered $\mathrm{P}_{(\mathrm{a}-\mathrm{A}) \mathrm{CO}_{2}}$ in patients with RDS compared to untreated controls. Findings of this study might not be relevant to other surfactants preparations since their effects sometimes vary. ${ }^{19}$ Unlike most other surfactants, Exosurf is entirely synthetic and lacks proteins. ${ }^{2}$ We could find only one study similar to ours (in abstract form) which showed no consistent changes in $\mathrm{P}_{(\mathrm{a}-\mathrm{A}) \mathrm{CO}_{2}}$ for $2 \mathrm{hr}$ following rescue surfactant. ${ }^{20}$ That study evaluated Beractant, a modified bovine surfactant which contains proteins (Survanta, Ross Laboratories, Columbus, Ohio). The fact that we used a different surfactant probably did not account for the dissimilar study results. The differences were more likely due to the much longer than $2 \mathrm{hr}$ long evaluation intervals in our study. Also, 8 of the 15 patients of Bowen et al. ${ }^{20}$ were nonresponders in whom surfactant did not significantly improve oxygenation. Our results concur with those authors' conclusion that surfactant does not appear to increase lung regions of high $\dot{V}_{\mathrm{A}} / \dot{Q}$, however, by our results, surfactant reduces high $\dot{V}_{A} / \dot{Q}$ lung regions over several hours.

Publications about the effects of surfactant on lung physiology can be categorized by the following functions (partial listing): oxygenation, ${ }^{2-5}$ lung compli- ance, ${ }^{5-7,21,22}$ other aspects of lung mechanics, ${ }^{5,21}$ blood flow patterns, ${ }^{4,22-26}$ gas exchange, ${ }^{27,28}$ and other issues. ${ }^{29}$ Surfactant effects on $\dot{V}_{A} / \dot{Q}$ have been studied relatively little, although some studies have noted widely varying $\mathrm{P}_{\mathrm{aCO}}$ levels. ${ }^{4,23-26}$ The $\mathrm{P}_{\mathrm{aCO}}$ of mechanically ventilated patients can usually be normalized by adjustments of the ventilator; therefore $\mathrm{PaCO}_{2}$ alone may not correctly assess the lung's ability to remove $\mathrm{CO}_{2}$. In a preliminary analysis of our study's patients $\mathrm{P}_{(\mathrm{a}-\mathrm{A}) \mathrm{CO}_{2}}$, but not $\mathrm{P}_{\mathrm{aCO}}$ or $\mathrm{P}_{\mathrm{etCO}}$, consistently had positive correlations with MAP. ${ }^{30}$ Since MAP is a rough gauge of ventilation requirements, ${ }^{31}$ ventilation was assessed best with $\mathrm{P}_{(\mathrm{a}-\mathrm{A}) \mathrm{CO}_{2}}$.

Trends in $\mathrm{P}_{(\mathrm{a}-\mathrm{A}) \mathrm{CO}_{2}}$ of healthy premature infants ${ }^{13}$ and in patients with $\mathrm{RDS}$ not treated with surfactant had been investigated. ${ }^{12,32}$ Tori et al. (see their Fig. 6) provided information regarding $\mathrm{P}_{(\mathrm{a}-\mathrm{A}) \mathrm{CO}_{2}}$ changes during the early phase of RDS. ${ }^{32}$ Progressive worsening of $\mathrm{P}_{(\mathrm{a}-\mathrm{A}) \mathrm{CO}}$, was observed in 6 of 6 individual patients with RDS: those for whom 2 or more $\mathrm{P}_{(\mathrm{a}-\mathrm{A}) \mathrm{CO}_{2}}$ values were obtained within the first 2 to 2-1/2 days of life (spacing between values was about $1 / 2$ to 2 days). This trend of worsening $\mathrm{P}_{(\mathrm{a}-\mathrm{A}) \mathrm{CO}_{2}}$ was thus similar to the pattern of our control group.

Our findings were consistent with studies by Krauss and Auld and others who showed that both high and low $\dot{\mathrm{V}}_{\mathrm{A}} / \dot{\mathrm{Q}}$ lung regions can occur simultaneously in RDS. ${ }^{12,32}$ Regions of low $\dot{\mathrm{V}}_{\mathrm{A}} / \dot{\mathrm{Q}}$ are important causes of poor oxygenation, ${ }^{12,32}$ but other causes include anatomic right-to-left shunts ${ }^{33}$ and diffusion block. ${ }^{32}$ To demonstrate regions of low $\dot{\mathrm{V}}_{\mathrm{A}} / \mathrm{Q}$ requires specialized analyses such as the arterial-alveolar difference of nitrogen. ${ }^{8-12,20,32}$ Our study did not include such an analysis, but we did show simultaneous occurrence of high $\mathrm{P}_{(\mathrm{a}-\mathrm{A}) \mathrm{CO}_{2}}$ and impaired oxygenation in RDS. Our findings were consistent with current knowledge that surfactant therapy in RDS almost always improves oxygenation. ${ }^{1-5}$

It is surprising that minimal correlations were found between the effects of surfactant on $\mathrm{P}_{(\mathrm{a}-\mathrm{A}) \mathrm{CO}_{2}}$ and on oxygenation (Table 4). This was the case regardless of which of the 3 oxygenation parameters was matched to $\mathrm{P}_{(\mathrm{a}-\mathrm{A}) \mathrm{CO}_{2}}$. Control infants had moderately positive correlations for these same parameters. The explanation of the minimal correlations in the surfactant group is probably related to different mechanisms involved in improving oxygenation and in improving $\mathrm{P}_{(\mathrm{a}-\mathrm{A}) \mathrm{CO}_{2}}$.

Surfactant improves oxygenation by increasing lung volume in underaerated regions $\mathrm{s}^{1,5,21}$ and by other mechanisms. ${ }^{29}$ All of these appear to mainly involve lung regions with $0 \leqslant \dot{\mathrm{V}}_{\mathrm{A}} / \dot{\mathrm{Q}}<1$. Therefore the effects of these mechanisms on $\mathrm{P}_{(\mathrm{a}-\mathrm{A}) \mathrm{CO}_{2}}$ would be minimal. ${ }^{8-11}$ Pulmonary underperfusion is one cause of high $\dot{\mathrm{V}}_{\mathrm{A}} / \dot{\mathrm{Q}}$ regions. Accordingly, relief of hypoxemia might reduce high $\dot{\mathrm{V}}_{\mathrm{A}} / \dot{\mathrm{Q}}$ regions by countering vasoconstriction, or by allowing MAP to be reduced (a high MAP would tend to 
collapse compliant pulmonary vessels). Alternatively, surfactant might normalize high $\dot{\mathrm{V}}_{\mathrm{A}} / \dot{\mathrm{Q}}$ regions by reducing regions of the lung which are overventilated. Our data are more consistent with the assumption that rescue Exosurf normalizes high $\dot{\mathrm{V}}_{\mathrm{A}} / \dot{\mathrm{Q}}$ regions mainly by reducing overventilation.

In conclusion, Exosurf rescue therapy for RDS reduced high $\dot{\mathrm{V}}_{\mathrm{A}} / \dot{\mathrm{Q}}$ mismatch over several hours, as shown by reductions in $\mathrm{P}_{(\mathrm{a}-\mathrm{A}) \mathrm{CO}_{2}}$. The exact mechanisms for this improvement were not determined by this study. Such mechanisms did not appear linked to the improved oxygenation caused by the surfactant. We speculate that the principal mechanism in reducing $\mathrm{P}_{(\mathrm{a}-\mathrm{A}) \mathrm{CO}_{2}}$ following surfactant is reduction of overventilation. Future study into clarifying the mechanisms of surfactant effects could help reveal the causes for differences between the results with various surfactants.

\section{REFERENCES}

1. Jobe AH. Pulmonary surfactant therapy. N Engl J Med. 1993; 328:861-868.

2. Long W, Thompson T, Sundell H, et al. Effects of two rescue doses of a synthetic surfactant on mortality rate and survival without bronchopulmonary dysplasia in 700- to 1350-gram infants with respiratory distress syndrome. J Pediatr. 1991; 1 18:595-605.

3. Long W, Corbet A, Cotton R, et al. A controlled trial of synthetic surfactant in infants weighing $1250 \mathrm{~g}$ or more with respiratory distress syndrome. N Engl J Med. 1991; 325:1696-1703.

4. Halliday HL, McCord FB, McClure BG, Reid MM. Acute effects of instillation of surfactant in severe respiratory distress syndrome. Arch Dis Child. 1989; 64:13-16.

5. Goldsmith LS, Greenspan JS, Rubenstein SD, Wolfson MR, Shaffer TH. Immediate improvement in lung volume after exogenous surfactant: alveolar recruitment versus increased distention. $\mathbf{J}$ Pediatr. 1991; 119:424-428.

6. Bhutani VK, Abbasi S, Long WA, Gerdes JS. Pulmonary mechanics and energetics in preterm infants who had respiratory distress syndrome treated with synthetic surfactant. J Pediatr. 1992; 120:S18-S24.

7. Armsby DH, Bellon G, Carlisle K, et al. Delayed compliance increase in infants with respiratory distress syndrome following synthetic surfactant. Pediatr Pulmonol. 1992; 14:206-213.

8. West JB. Ventilation/Blood Flow and Gas Exchange. Oxford: Blackwell Scientific Publications, 1990; 1-120.

9. Farhi LE. Ventilation-perfusion relationship and its role in alveolar gas exchange. In: Caro CG, ed. Advances in Respiratory Physiology. Baltimore: Williams \& Wilkins, 1966; 149-197.

10. Krauss AN. Ventilation-perfusion relationship in neonates. In: Thibeault DW, Gregory GA, eds. Neonatal Pulmonary Care. Norwalk, CT: Appleton-Century-Crofts, 1986; 123-147.

11. Truog WE. Pulmonary gas exchange in the developing lung. In: Polin RA, Fox WW, eds. Fetal and Neonatal Physiology, Vol. 1. Philadelphia: WB Saunders, 1992; 842-852.

12. Hand IL, Shepard EK, Krauss AN, et al. Ventilation-perfusion abnormalities in the preterm infant with hyaline membrane disease: A two-compartment model of the neonatal lung. Pediatr Pulmonol. 1990; 9:206-213.

13. Krauss AN, Auld PAM. Ventilation-perfusion abnormalities in the premature infant: Triple gradient. Pediatr Res. 1969; 3:255-264.
14. Swedlow DB. Capnometry and capnography: The anesthesia disaster early earning system. Semin Anesth. 1986; 5:194-205.

15. Meredith KS, Monaco FJ. Evaluation of a mainstream capnometer and end-tidal carbon dioxide monitoring in mechanically ventilated infants. Pediatr Pulmonol. 1990; 9:254-259.

16. Nicks JJ, Schram MS, Schumacher RE. Continuous end-tidal $\mathrm{CO}_{2}$ monitoring reflects disease severity in the newborn respiratory distress syndrome [Abstract]. Pediatr Res. 1987; 21:461 A.

17. Moorthy SS, Losasso AM, Wilcox J. End-tidal $\mathrm{PCO}_{2}$ greater than $\mathrm{PaCO}_{2}$. Crit Care Med. 1984; 12:534 535.

18. Munro BH. Correlation. In: Munro BH, Visintainer MA, Page EB, eds. Statistical Methods for Health Care Research. Philadelphia: JB Lippincott, 1986; 63-85.

19. Cummings JJ, Holm BA, Hudak ML, Hudak BB, Ferguson WH, Egan EA. A controlled clinical comparison of four different surfactant preparations in surfactant-deficient preterm lambs. Am Rev Respir Dis. 1992; 145:999-1004.

20. Bowen WM, Rivera CE, Krauss AN, Auld PAM. $\dot{\mathrm{V}}_{\mathrm{A}} / \mathrm{Q}$ Relationships $0-120$ minutes after surfactant [Abstract]. Pediatr Res. 1993; 33:318A

21. Svenningsen NW. Pulmonary functional residual capacity and lung mechanics in surfactant-treated infants. Semin Perinatol. 1992; 16:181-185.

22. Heldt GP, Pesonen E, Merritt TA, Elias W, Sahn DJ. Closure of the ductus arteriosus and mechanics of breathing in preterm infants after surfactant replacement therapy. Pediatr Res. 1989; 25:305-310.

23. Pfenninger J, Aebi C, Bachmann D, Wagner BP. Lung mechanics and gas exchange in ventilated preterm infants during treatment of hyaline membrane disease with multiple doses of artificial surfactant (Exosurf). Pediatr Pulmonol. 1992; 14:10-15.

24. Kinsella JP, Gerstmann DR, Gong AK, Taylor AF, deLemos RA. Ductal shunting and effective systemic blood flow following single dose surfactant treatment in the premature baboon with hyaline membrane disease. Biol Neonate 1991; 60:283-291.

25. Clyman RI, Jobe A, Heymann M, et al. Increased shunt through the patent ductus arteriosus after surfactant replacement therapy. $\mathrm{J}$ Pediatr. 1982; 100:101-107.

26. Vidyasagar D, Maeta $H$, Raju TNK, et al. Bovine surfactant (Surfactant TA) therapy in immature baboons with hyaline membrane disease. Pediatries 1985; 75:1132-1142.

27. Cotton RB. A model of the effect of surfactant treatment on gas exchange in hyaline membrane disease. Semin Perinatol. 1994; 18:19-22.

28. Hazan J, Chessex P, Piedboeuf B, Bourgeois M, Bard H, Long W. Energy expenditure during synthetic surfactant replacement therapy for neonatal respiratory distress syndrome. J Pediatr. 1992; 120:S29-S33.

29. Liu M, Wang L, Li E, Enhorning G. Pulmonary surfactant will secure free airflow through a narrow tube. J Appl Physiol. 1991; 71:742-748.

30. Billman D, Nicks J, Schumacher R. Capnography determinations of arterial-alveolar gradients of carbon dioxide: Positive correlation with mean airway pressure [Abstract]. Clin Res. 1989; 37: 956A.

31. Boros SJ, Matalon SV, Ewald R, Leonard AS, Hunt CE. The effect of independent variations in inspiratory-expiratory ratio and end expiratory pressure during mechanical ventilation in hyaline membrane disease: The significance of mean airway pressure. $\mathrm{J}$ Pediatr. 1977; 91:794-798.

32. Tori CA, Krauss AN, Auld PAM. Serial studies of lung volume and VA/Q in hyaline membrane disease. Pediatr Res. 1973; 7: $82-88$.

33. Walther FJ, Benders MI, Leighton JO. Persistent pulmonary hypertension in premature neonates with severe respiratory distress syndrome. Pediatrics 1992; 90:899-904. 